\title{
Scope and data set of the phytosociological database 'Grasslands in the Polish Carpathians'
}

\author{
Joanna Korzeniak* \\ Institute of Nature Conservation of the Polish Academy of Sciences, Al. Mickiewicza 33, 31-120 Cracow, Poland
}

\begin{abstract}
The phytosociological database as a tool for synthetic and comprehensive study of semi-natural meadows in the Polish part of the Carpathians is presented. It has been developed in the Institute of Nature Conservation of the Polish Academy of Sciences since 2007. All accessible phytosociological relevés were digitalized and stored in a TURBOVEG database. As of January 2013, 4620 relevés have been collected in the database, chiefly from mesic meadows of Arrhenatherion alliance (76\%) and mat-grass swards of Nardo-Callunetea class (18\%). They were recorded between 1923 and 2012 at an altitude range of 195-2000 m above sea level. For improving territorial coverage of the region by vegetation sampling, since 2009 an extensive field survey has been carried out to collect data from previously unexplored areas and record the actual stage of semi-natural grasslands. As a result 1146 recent unpublished relevés were collected. The statistics of available resources, discussion on the data quality and the application prospects of the database are outlined. The database "Grasslands in the Polish Carpathians" is an intrinsic part of the research on the diversity of vegetation in the Polish Carpathian grasslands, as well as a record of the changes it undergoes.
\end{abstract}

Keywords: Arrhenatheretalia, meadows, Nardus stricta swards, phytosociology, Poland, relevé, vegetation sampling

\section{Introduction}

Phytosociological relevés provide an important source of information on vegetation, as they contain basic data on species co-occurrence in a particular time and space. Owing to the simple standard procedure of data acquisition and a longstanding tradition of phytosociology in Western and Central Europe, it was possible for those regions to collect resources estimated at approximately 4300000 records [1]. The dynamic development of software for archiving and analyzing large phytosociological data-sets in the early 1990s, made it increasingly common to gather information in the form of electronic databases. At the turn of 20th and 21st centuries the number of digitalized relevés was assessed as 1 million, out of which 750000 came from Central and Western Europe [2]. As the amount of data in vegetation-plot databases is constantly growing, the Global Index of Vegetation-Plot Databases (GIVD) - an online portal containing meta-data on existing databases - was created on the initiative of German botanists in August 2010,

\footnotetext{
*Email: korzeniak@iop.krakow.pl
}

Handling Editor: Zygmunt Kącki

This is an Open Access digital version of the article distributed under the terms of the Creative Commons Attribution 3.0 License (creativecommons.org/licenses/by/3.0/), which permits redistribution, commercial and non-commercial, provided that the article is properly cited. which has substantially facilitated the flow of information and the transfer of data $[3,4]$.

Vegetation-plot databases are used, above all, in studies concerning the variability of species and habitats, as well as their relationships with environmental conditions $[5,6]$, the assessment of biodiversity, macro-scale studies in vegetation ecology and global change research [3,7]. However, they are mostly designed for vegetation classification, especially on a large spatial scale [8-11].

The number of relevés from Poland has been estimated as 180000 [1]. In the Polish Vegetation Database [12,13], developed in the University of Wrocław since 2007, 39170 relevés have been digitalized using TURBOVEG software [14]. The majority of relevés come from southwestern and western Poland. The Carpathians are mainly represented by the data from classic phytosociological studies from the Beskid Śląski and Beskid Żywiecki Mts., the Babia Góra Range, the Gorce Mts., Pieniny Klippen Belt and the Beskid Sądecki Mts. [14].

The idea of creating a regional database covering the data concerning the vegetation of Carpathian grasslands was conceived in the Institute of Nature Conservation of the Polish Academy of Sciences in Kraków, independently and at approximately the same time as the similar initiative undertaken by the University of Wrocław. It stemmed from the need to supplement and update the data concerning mesic semi-natural grassland vegetation, very susceptible to land-use changes. Over the last few decades, land abandonment and decline in traditional farming practices have been recognized as the main threat to biodiversity, particularly marked in mountain areas of Europe [15]. Disappearance of thermophilic and oligotrophic grassland associations, as well as small, light demanding plant species as 
a consequence of deep decline of agriculture in less productive areas at the higher altitudes, and developing of species-poor communities associated with more fertile and moist habitats are reported also from the Polish Carpathians [16-18].

The classification system of mountain grassland communities in Poland originates from regional phytosociological studies dating back to 1960s and 1970s and remains largely unaltered to this day [19]. Unlike in the Czech Republic or Slovakia $[8-10,20]$, the system has not been validated by numerical methods. Furthermore, the knowledge of the current preservation state of these phytocoenoses is fragmentary, and results of Natura 2000 habitat monitoring indicate the deterioration in their condition [21].

The objective of this article is to present the phytosociological database of grassland vegetation in the Polish Carpathians, to describe its resources, and to discuss the quality of data, as well as the usability of the database in the research on grassland vegetation.

\section{Storing up and collecting vegetation data}

Phytosociological relevés are stored in a TURBOVEG database, recognized as a binding standard in the European Vegetation Survey [22,23] and compatible with software used in vegetation data analysis [24]. The database resources mainly comprise relevés from semi-natural mesic meadows of $A r$ rhenatherion elatioris, Molinia meadows (Molinion caeruleae), as well as the formerly widespread but currently declining mat-grass swards of the order Nardetalia.

After inventorying the available phytosociological data, the insufficiently explored areas of grassland vegetation were identified. In order to achieve a more even distribution of data and record the present stage of grasslands, a field survey has being carried out since 2009 . The relevés were performed in plots exceeding $16 \mathrm{~m}^{2}$ [25], usually $25 \mathrm{~m}^{2}$, and the species cover-abundance was evaluated using the extended, 9-point, Braun-Blanquet scale [26]. Apart from the standard data, any available information on the land use (the way of use, intensity, frequency, past use, and the duration of out-of-use periods) was also recorded.

\section{Resources - basic statistics}

Until January 2013, 4620 relevés recorded by 57 authors at an altitude range of 195 to $2000 \mathrm{~m}$ above sea level have been archived in the base. The oldest relevés date back to 1923, and represent mat-grass communities and mountain mesic meadows in the Western Tatra Mts. [27]. The authorship of as many as two thirds of the relevés is attributed to no more than 17 people (Tab. 1). The published relevés constitute $60 \%$ of the data collected and come from 52 studies. The most significant amount of data was obtained from the following journals: Fragmenta Floristica et Geobotanica (606 relevés), Zeszyty Naukowe UJ (246), Prace Botaniczne (234), Zeszyty Naukowe Uniwersytetu Rolniczego im. H. Kołłątaja w Krakowie (236) and Studia Naturae (231). Approximately 5\% of the database resources are relevés from doctoral dissertation manuscripts, studies on the vegetation cover in protected areas and natural science expert reports prepared as part of the agri-environmental program. The quality of the latter is fairly varied. The rest of the data are unpublished relevés from 1996-2012. More than half of them
Tab. 1 Most frequently represented authors of the relevés stored in the base.

\begin{tabular}{|c|c|c|c|}
\hline \multirow[b]{2}{*}{ Author } & \multicolumn{3}{|c|}{ Number of relevés } \\
\hline & Published & Unpublished & Total \\
\hline J. Zarzycki & 321 & 456 & 777 \\
\hline J. Korzeniak & 185 & 157 & 342 \\
\hline A. Koczur & 27 & 301 & 328 \\
\hline M. Kozak & 228 & 41 & 269 \\
\hline J. Korzeniak \& A. Kalemba & 0 & 248 & 248 \\
\hline M. Nowak \& R. Kostuch & 239 & 0 & 239 \\
\hline D. Suder & 0 & 222 & 222 \\
\hline R. Kaźmierczakowa, J. & 148 & 0 & 148 \\
\hline \multicolumn{4}{|l|}{ Zarzycki, I. Wróbel \& G. } \\
\hline \multicolumn{4}{|l|}{ Vončina } \\
\hline J. Kornaś \& A. Medwecka- & 115 & 0 & 115 \\
\hline \multicolumn{4}{|l|}{ Kornaś } \\
\hline S. Kucharzyk & 0 & 103 & 103 \\
\hline E. Dubiel, A. Stachurska \& S. & 102 & 0 & 102 \\
\hline Gawroński & & & \\
\hline
\end{tabular}

(1146 relevés) were recorded recently, mostly in the regions that lacked data: the foothill belt, the Western and Central Beskidy Mts. and the Orawa-Podhale Depression (Fig. 1).

Temporal coverage of relevés stored in the database varies considerably (Fig. 2) and reflects the history of research on grassland vegetation in this part of Poland. The main body of the archival material dates back to 1960s and 1970s and refers to the mountain areas of the greatest natural value, namely: Tatra Mts. and Sub-Tatra region [28,29], Polica Range [30], Gorce Mts. [31] and the Bieszczady Mts. [32]. Numerous studies were also carried out at the same period by grassland scientists: R. Kostuch and M. Nowak in the Western and Central Beskidy Mts., and the Western Bieszczady Mts., although, their quality does not match the classic phytosociological accounts. The 1990s and the first decade of the 21th century brought studies of non-forest vegetation in national parks [33-36], as well as the Gorce Mts. [17], Radziejowa Range [18], Beskid Śląski Mts. [37], Beskid Mały Mts. [38] and Żywiec Basin [39]. Given the existence of high quality contemporary and historic data concerning the Gorce Mts., Pieniny Klippen Belt, and the highest part of the Bieszczady Mts., they can be considered to be thoroughly explored, whereas the grasslands of the submontane zone are only sparsely covered in the phytosociological studies.

The most frequent relevés in the database are these assigned by authors to Arrhenatheretum elatioris (1076 relevés) and Gladiolo-Agrostietum (900 relevés). More than half of the mesic meadow relevés has no affiliation to any association of the current classification system used in Poland (Tab. 2). The small number of relevés from the Molinion alliance (23) results from its scarcity in the Polish Carpathians. Mat-grass swards (858 relevés) are mainly represented by phytocoenoses from the montane and subalpine zone, and have been only sporadically noted at the lower altitudes.

\section{Data quality}

The database is a collection of all available relevés, recorded by authors with different skill sets, aimed at various and 


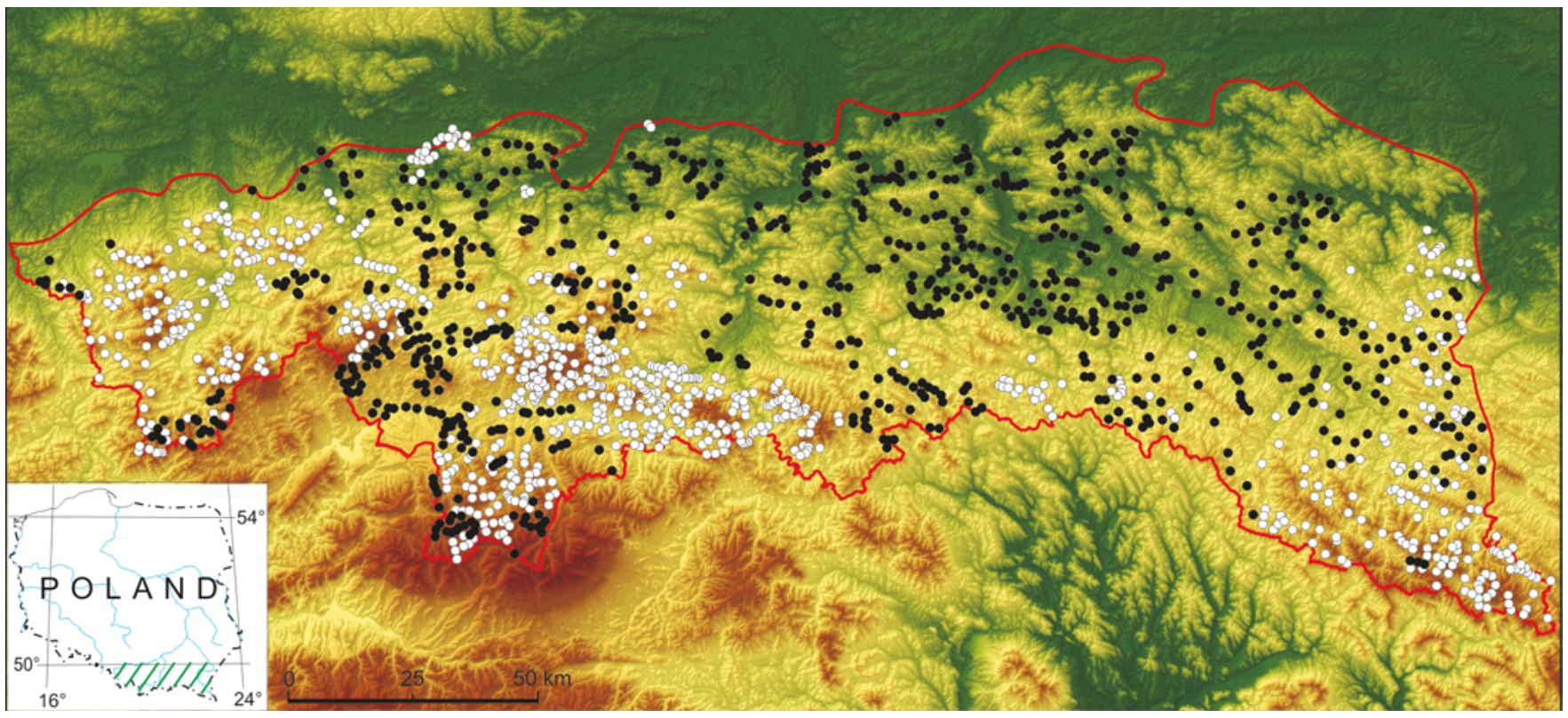

Fig. 1 Distribution of relevés stored in the phytosociological database "Grasslands in the Polish Carpathians". Black circles indicate unpublished data collected in 2009-2012.

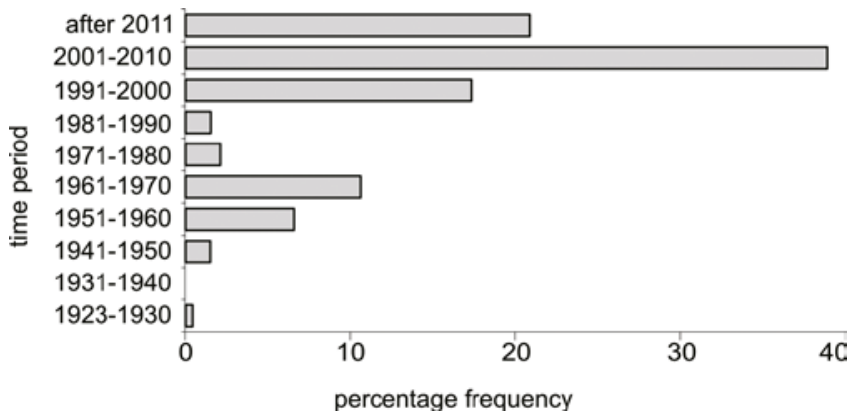

Fig. 2 Percentage share of relevés from subsequent decades stored in the database.

Tab. 2 Syntaxonomical units included in the database.

Molinio-Arrhenatheretea: Junco-Molinietum, Molinietum caeruleae, Deschampsia caespitosa community, Alopecuretum pratensis, Holcetum lanati (Holcus lanatus community)*, Arrhenatheretum elatioris, GladioloAgrostietum capillaris, Anthyllidi-Trifolietum montani, Campanula patulaTrisetum flavescens community*, Anthriscus sylvestris community*, Agrostis capillaris community*, Leontodon hispidus-Anthoxanthum odoratum community ${ }^{*}$, Holcus mollis community ${ }^{*}$, Alchemilletum pastoralis ${ }^{*}$, Phyteumo (orbicularis)-Trifolietum pratensis, Poo-Festucetum rubrae (Poa pratensis-Festuca rubra community) ${ }^{\star}$, Festucetum rubrae (Festuca rubra community)*, Trisetum flavescens community ${ }^{*}$, LolioCynosuretum, Festuco-Cynosuretum, Anthoxantho-Agrostietum *

Nardo-Callunetea: Hieracio vulgati-Nardetum, Leonotodono autumnalisNardetum ${ }^{*}$,Hypochoeridi-Nardetum ${ }^{*}$,Geo montani-Nardetum ${ }^{*}$, Hieracio alpini-Nardetum, Festuca picta community ${ }^{*}$, Deschampsia flexuosa community ${ }^{*}$ Polygalo-Nardetum, Calluno-Nardetum strictae, NardoJuncetum squarrosi, Carlino-Dianthetum deltoidis ${ }^{\star}$

* Plant associations not mentioned in the classification system of vegetation units in Poland [19]. individual scientific purposes, during a 90-year period, which involved altering the taxonomic affiliation of numerous species. The data quality is therefore inevitably variable throughout the database, which is intrinsic to this type of project [40]. According to the commonly accepted standards [41], any simplified relevés with incomplete lists of species, or the ones covering very small plots for this type of vegetation (below $4 \mathrm{~m}^{2}$ ), as well as those where strong doubts persist as to whether the species were correctly identified, have not been entered into the database. A batch containing 3681 relevés ( $85 \%$ ) has a specified date, plot area, georeferences and altitude (Tab. 3). The exact location measured with a GPS receiver is provided for 2348 relevés from the last few years (54\%). Based on maps and site descriptions, georeferences were determined a posteriori for $36 \%$ of relevés. These values are usually accurate to $0.5-1 \mathrm{~km}$. The data most frequently missing in the headers of relevés concerns the vertical and horizontal vegetation structure.

Data from phytosociological databases are typically characterized by uneven spatial distribution, hence the need to use special tools during the analyses, e.g. geographic stratification [42]. In the Polish part of the Carpathians, the areas of the highest natural value are intensively sampled. The oversampling effect was reduced by actively supplementing the database with the material from the most under-represented mesoregions, e.g. submontane zone and the less explored parts of the Beskidy Mts.

Tab. 3 Percentage of basic information missing.

No. Variable $\quad \%$ of missing values

$\begin{array}{lc}\text { Date (at least month and year) } & 3 \\ \text { Relevé area } & 6 \\ \text { Georeferences } & 10 \\ \text { Altitude } & 7 \\ \text { Cover of herb layer } & 10 \\ \text { Average height of herb layer } & 35 \\ 1 \text { or } 2 \text { or } 3 \text { or } 4 & 15\end{array}$




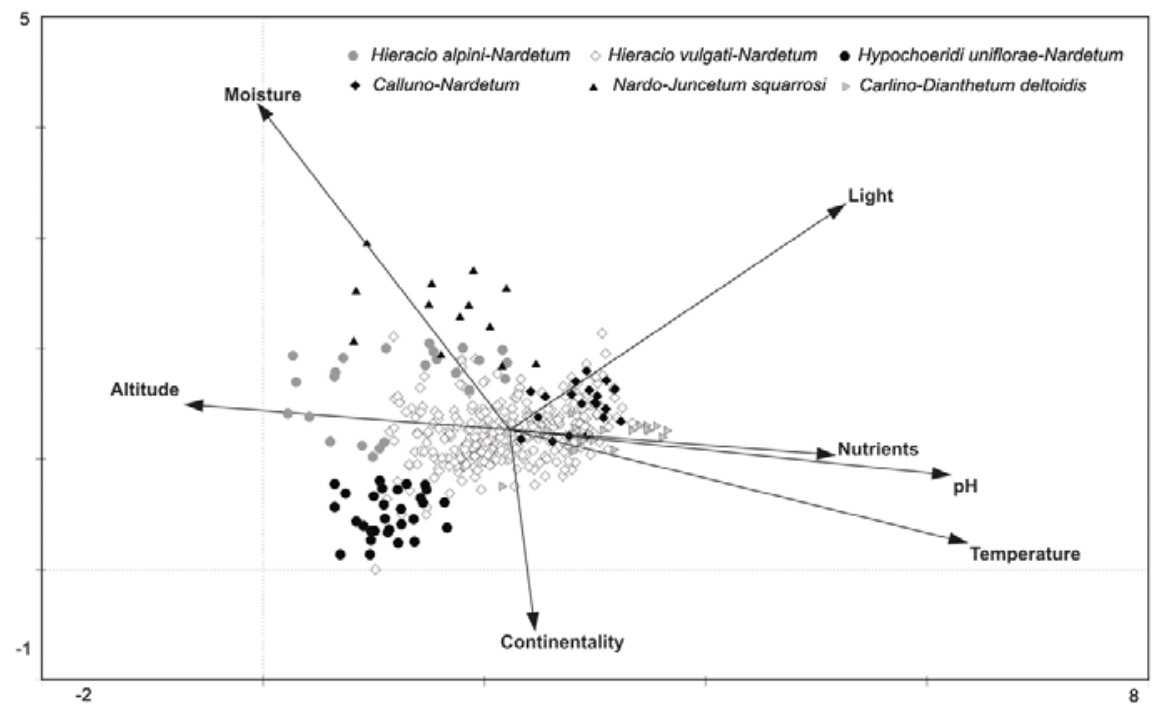

Fig. 3 Detrended correspondence analysis (DCA) of mat-grass communities (Nardetalia) based on square-root transformed cover data. Supplementary environmental variables represent unweighted average Ellenberg indicator values and altitude.

A remediable, and therefore a less essential drawback, is the plethora of syntaxa. Approximately $35 \%$ of the relevés in the database represent associations and communities not included in the classification system currently used in Poland (Tab. 2). Some of them certainly reflect the arbitrary views of the authors who tended to put associations into very narrow categories; another may illustrate the actual temporal and spatial variability of the vegetation. To clear up the relationships among these syntaxa, a comparison of traditional classification system with results of numerical or supervised classification is needed [9-11].

\section{Application of the database to the vegetation studies}

The main role of the database is to supply researchers with information adequate for the synthetic evaluation of the grassland plant communities and can be used as a data source for investigating the main spatial and temporal environmental gradients. For example, in oligothrophic grasslands with Nardus stricta results of detrended correspondence analysis (DCA) performed for 442 relevés showed two main gradients in vegetation diversity (Fig. 3). The first axis (eigenvalue 0.3348) correlates mostly with altitude $(r=-0.9346)$, the second axis (eigen value $0.2329)$ correlates mostly with continentality $(r=-0.2817)$ and light $(r=0.2550)$. The initial data set contained 822 relevés, originally assigned to Nardetalia order or with Nardus stricta cover $>20 \%$. But to reduce the oversampling effect on the analyses, relevés were geographically stratified [42] within the main association types.

In order to determine temporal changes in the species composition, the analyzed dataset was divided into two time periods related to land use changes in Poland in the 1990s. Only four plant associations were represented by historical and current relevés (Fig. 4). In oligotrophic grasslands, after the changes in land-use, increasing of species with higher nutrient and moisture Ellenberg indicator value occurred. Similarly to mesic meadows [16-18], the data showed decrease of light demanding species. Relatively high number of species in Hypochoeridi uniflorae-Nardetum and Hieracio-Nardetum after 1994 is probably the result of secondary succession and encroachement of species associated with other habitats.
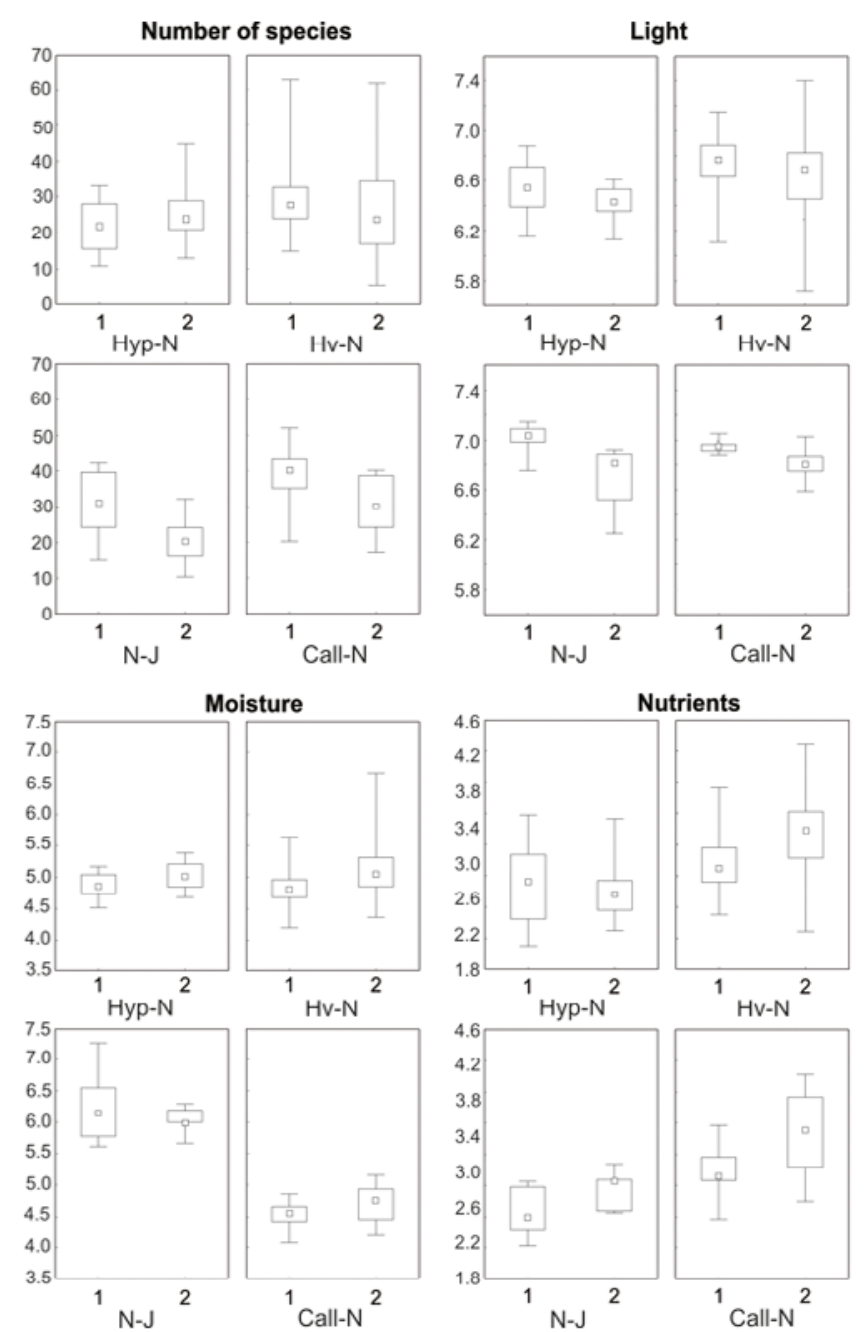

Fig. 4 Temporal changes in the species richness and Ellenberg indicator values in four Nardetalia associations: Hyp-N - Hypochoeridi uniflorae-Nardetum; Hv-N - Hieracio vulgati-Nardetum; N-J - NardoJuncetum squarrosi; Call-N - Calluno-Nardetum. Median, quartiles and ranges are shown. 1 - 1923-1988; 2 - 1994-2012. 


\section{Conclusions}

Given its rich resources and the active acquisition of data from the least sampled areas, the phytosociological database of grasslands in the Polish Carpathians provides historical and contemporary information. The quality of data is relatively high, comparable with the Czech database [40], or the Slovakian resources concerning the grassland [43] and mountain [44] vegetation. Our database can serve as a starting point for comprehensive analysis of the grassland communities variability and development of the classification system adequate to profound land-use changes during the last 50 years. It also presents an important supplement to the national database. As of January 2013, the Polish Vegetation Database comprised 6818 relevés of the Molinio-Arrhenathereatea class meadows and 495 relevés of the Nardo-Callunetea class mat-grass communities [14]. The Carpathian grassland database contains 3601 and 858 relevés respectively.

Our intention was to develop the database that may be used for investigations of spatial and temporal changes in vegetation diversity of Polish Carpathian meadows and pastures. These habitats are vulnerable to changes in agriculture practices, therefore the database can also serve as a tool for their monitoring and conservation (inter alia, to identify indicator species for Natura 2000 habitats, determine the "hot spots" for endangered species and syntaxa, and to assess the degree of syntaxa transformation).

The database is planned to be operated and made available from GIVD, which should facilitate the further syntaxonomical synthesis of grassland ecosystems in the whole Carpathians (cf. $[9,10])$. As a long-term prospect it may become a part of the information system of European projects aimed at the largescale assessment of biodiversity, such as SynBioSys Europe [45].

\section{Acknowledgments}

I wish to express my sincere thanks to J. Zarzycki, M. Kozak, A. Koczur, R. Krause, I. Wróbel, S. Kucharzyk, A. Szary, P. Nejfeld, D. Suder, M. Jaźwa, K. Kozłowska and K. Stawowczyk for making their unpublished and published digitalized phytosociological data available; to the Chief Inspectorate of Environmental Protection for giving access to the relevés recorded during the monitoring of habitats; and to the Regional Directorates for Environmental Protection in Kraków and Rzeszów for phytosociological materials from the agri-environmental programs. My warm thanks go to H. Kuciel and A. Kalemba for their help in archiving the data.

The database "Grasslands in the Polish Carpathians" is developed with funding from the National Science Center grant No. N N305 283137.

\section{References}

1. Schaminée JHJ, Hennekens SM, Chytrý M, Rodwell JS. Vegetation-plot data and databases in Europe: an overview. Preslia. 2009;81:173-185.

2. Ewald J. Der Beitrag pflanzensoziologischer Datenbanken zur vegetationsökologischen Forschung. Ber R-Tüxen Ges. 2001;13:53-69.

3. Dengler J, Jansen F, Glöckler F, Peet RK, De Cáceres M, Chytrý M, et al. The Global Index of Vegetation-Plot Databases (GIVD): a new resource for vegetation science. J Veg Sci. 2011;22(4):582-597. http://dx.doi. org/10.1111/j.1654-1103.2011.01265.x
4. Global Index of Vegetation-Plot Databases [Internet]. 2012 [cited 2012 Sep 10]; Available from: http://www.givd.info/558.html

5. Jandt $\mathrm{U}$, von Wehrden $\mathrm{H}$, Bruelheide H. Exploring large vegetation databases to detect temporal trends in species occurrences. J Veg Sci. 2011;22(6):957-972. http://dx.doi.org/10.1111/j.1654-1103.2011.01318.x

6. Voss N, Simmering D, Peppler-Lisbach C, Durka W, Eckstein RL. Vegetation databases as a tool to analyse factors affecting the range expansion of the forest understory herb Ceratocapnos claviculata. J Veg Sci. 2011;22(4):726-740. http://dx.doi.org/10.1111/j.1654-1103.2011.01284.x

7. Duckworth JC, Bunce RGH, Malloch AJC. Vegetation gradients in Atlantic Europe: the use of existing phytosociological data in preliminary investigations on the potential effects of climate change on British vegetation. Glob Ecol Biogeogr. 2000;9(3):187-199. http://dx.doi. org/10.1046/j.1365-2699.2000.00161.x

8. Chytrý M, editor. Vegetace České republiky 1 . Travinná a keříčková vegetace. Prague: Academia; 2007.

9. Janišová $\mathrm{M}$, Hájková $\mathrm{P}$, Hegedüšová $\mathrm{K}$, Hrivnák R, Kliment J, Michálková $\mathrm{D}$, et al. Travinnobylinná vegetácia Slovenska - elektronický expertný systém na identifikáciu syntaxónov. Bratislava: Botanický ústav SAV; 2007.

10. Rozbrojová Z, Hájek M, Hájek O. Vegetation diversity of mesic meadows and pastures in the West Carpathians. Preslia. 2012;82:307-332.

11. Knollová I, Chytrý M, Tichý L, Hájek O. Local ranges of phytosociological associations: are they reflected in numerical classification? Biol Bratisl. 2006;61(1):71-77. http://dx.doi.org/10.2478/s11756-006-0010-3

12. Kącki Z, Śliwiński M. The Polish Vegetation Database: structure, resources and development. Acta Soc Bot Pol. 2012;81(2):75. http://dx.doi. org/10.5586/asbp.2012.014

13. Kącki Z, Śliwiński M. Polish Vegetation Database [Internet]. In: Dengler J, Oldeland J, Jansen F, Chytrý M, Ewald J, Finckh M, et al., editors. Vegetation databases for the 21st century. Hamburg: BEE, Biocentre Klein Flottbek and Botanical Garden, University of Hamburg; 2012. p. 411-411. (Biodivers Ecol; vol 4). http://dx.doi.org/10.7809/b-e.00199

14. Polish Vegetation Database [Internet]. 2013 [cited 2013 Jan 8]; Available from: http://synbiot.uni.wroc.pl/

15. MacDonald D, Crabtree JR, Wiesinger G, Dax T, Stamou N, Fleury P, et al. Agricultural abandonment in mountain areas of Europe: environmental consequences and policy response. J Env Manage. 2000;59(1):47-69. http:// dx.doi.org/10.1006/jema.1999.0335

16. Zarzycki J, Kaźmierczakowa R. Przemiany ląk świeżych i pastwisk w Pienińskim Parku Nardowym w ciągu ostatnich 35 lat XX wieku. Stud Naturae. 2006;54(1):275-304.

17. Kozak M. Zróżnicowanie zbiorowisk łąkowych w Gorcach (Polskie Karpaty Zachodnie). Zesz Nauk UJ Pr. Bot. 2007;41:1-174.

18. Zarzycki J. Roślinność łąkowa pasma Radziejowej (Beskid Sądecki) i czynniki wpływające na jej zróżnicowanie. Zesz Nauk Uniw Roln. 2008;448:1-113.

19. Matuszkiewicz W. Przewodnik do oznaczania zbiorowisk roślinnych Polski. Warsaw: Polish Scientific Publishers PWN; 2001.

20. Jarolímek I, Šibik J. Diagnostic, constant and dominant species of the higher vegetation units of Slovakia. Bratislava: Veda; 2008.

21. Monitoring gatunków i siedlisk przyrodniczych [Internet]. 2013 [cited 2013 Jan 8]; Available from: http://www.gios.gov.pl/siedliska/

22. Hennekens SM, Schaminée JHJ. TURBOVEG, a comprehensive data base management system for vegetation data. J Veg Sci. 2001;12(4):589-591. http://dx.doi.org/10.2307/3237010

23. Rodwell JS, Pignatti S, Mucina L, Schaminée JHJ. European Vegetation Survey: update on progress. J Veg Sci. 1995;6(5):759-762. http://dx.doi. org/10.2307/3236447

24. Šibik J, Šibikova I. Vegetačná databáza - možnosti a využitie. Vegetation database - facilities and utilities. Bull Slov Bot Spoločn Bratisl. 2009;31(2):122-125.

25. Chytrý M, Otýpková Z. Plot sizes used for phytosociological sampling of European vegetation. J Veg Sci. 2003;14(4):563-570. http://dx.doi. org/10.1111/j.1654-1103.2003.tb02183.x 
26. Barkman JJ, Doing H, Segal S. Kritische Bemerkungen und Vorschläge zur Quantitativen Vegetationsanalyse. Acta Bot Neerl. 1964;13:394-419.

27. Szafer W, Pawłowski B, Kulczyński S. Zespoły roślin w Tatrach. Cz. III: Zespoły roślin w dolinie Kościeliskiej. Die Pflanzenassoziationen des Tatra-Gebirges. III T.: Die Pflanzenassoziationen des Kościeliska-Tales. Bull Acad Pol Sci Lettr Cl Math-Nat Ser B. 1926;2 Suppl:11-79.

28. Pawłowski B, Pawłowska S. Zespoły roślinne kośnych łąk północnej części Tatr i Podtatrza. Fragm Flor Geobot. 1960;6(2):95-222.

29. Grodzińska K. Zespoły łąkowe i polne Wzniesienia Gubałowskiego. Fragm Flor Geobot. 1961;7(2):357-418.

30. Stuchlikowa B. Zespoły ląkowe Pasma Policy w Karpatach Zachodnich. Fragm Flor Geobot. 1967;13(3):357-402.

31. Kornaś J, Medwecka-Kornaś A. Zespoły roślinne Gorców. I. Naturalne i na wpół naturalne zespoły nieleśne. Fragm Flor Geobot. 1967;13(2):167-316.

32. Pałczyński A. Łąki i pastwiska w Bieszczadach Zachodnich. Roczn Nauk Roln. 1962;99, D:1-129.

33. Zarzycki J. Ekologiczne podstawy kształtowania ekosystemow łąkowych Babiogórskiego Parku Narodowego. Stud Naturae. 1999;45:1-97.

34. Kaźmierczakowa R, Zarzycki J, Wróbel I, Vončina G. Łąki, pastwiska i zbiorowiska siedlisk wilgotnych Pienińskiego Parku Narodowego. Stud Naturae. 2004:49:195-251.

35. Denisiuk Z, Korzeniak J. Zbiorowiska nieleśne krainy dolin Bieszczadzkiego Parku Narodowego. Monogr Bieszcz. 1999;5:1-162.

36. Dubiel E, Stachurska A, Gawroński S. Nieleśne zbiorowiska roślinne Magurskiego Parku Narodowego (Beskid Niski). Pr Bot. 1999;33:1-60.
37. Wilczek Z. Fitosocjologiczne uwarunkowania ochrony przyrody Beskidu Śląskiego (Karpaty Zachodnie). Pr Nauk US. 2006;2481:1-222.

38. Stebel A. Roślinność nieleśna Beskidu Małego [PhD thesis]. Katowice: Katedra Geobotaniki i Ochrony Przyrody Uniwersytetu Śląskiego; 1997.

39. Nejfeld P. Zbiorowiska roślinne Kotliny Żywieckiej [PhD thesis]. Katowice: Katedra Geobotaniki i Ochrony Przyrody Uniwersytetu Śląskiego; 2005.

40. Chytrý M, Rafajová M. Czech National Phytosociological Database: basic statistics of the available vegetation-plot data. Preslia. 2003;75:1-15.

41. Mucina L, Schaminée JHJ, Rodwell JS. Common data standards for recording relevés in field survey for vegetation classification. J Veg Sci. 2000;11(5):769-772. http://dx.doi.org/10.2307/3236581

42. Knollová I, Chytrý M, Tichý L, Hájek O. Stratified resampling of phytosociological databases: some strategies for obtaining more representative data sets for classification studies. J Veg Sci. 2005;16(4):479-486. http:// dx.doi.org/10.1111/j.1654-1103.2005.tb02388.x

43. Janišová M, Škodová I. Phytosociological database of Slovak grassland vegetation. Ann Bot (Roma). 2007;7:19-26.

44. Šibíková I, Šibík J, Jarolímek I, Kliment J. Current knowledge and phytosociological data on the high-altitude vegetation in the Western Carpathians - a review. Biol Bratisl. 2009;64(2):215-224. http://dx.doi.org/10.2478/ s11756-009-0032-8

45. Schaminée JHJ, Hennekens SM, Ozinga WA. Use of the ecological information system SynBioSys for the analysis of large datasets. J Veg Sci. 2007;18(4):463-470. http://dx.doi.org/10.1111/j.1654-1103.2007.tb02560.x 